\section{Correspondence between children's nutritional status and mothers' perceptions: a population-based study}

\author{
Correspondência entre o estado nutricional de \\ crianças e a percepção materna: \\ um estudo populacional
}

\author{
${ }_{1}$ Centro de Ciencias da \\ Saúde, Universidade Federal \\ do Espírito Santo, Vitória, \\ Brasil. \\ 2 Centro Biomédico, \\ Universidade Federal do \\ Espírito Santo, Vitória, Brasil. \\ 3 Universidad Autónoma de \\ Madrid, Madrid, España. \\ Correspondence \\ M. C. B. Molina \\ Centro de Ciências da Saúde, \\ Universidade Federal do \\ Espírito Santo. \\ Av. Marechal Campos 1468, \\ Vitória, ES \\ 29000-000, Brasil. \\ mdmolina@uol.com.br
}

\section{Abstract}

This study aimed to investigate the correspondence between the nutritional status of children aged 7-10 years and their mothers' perceptions of their children's weight. A cross-sectional survey was conducted among 1,282 children. Weight and height were measured and classified according to International Obesity Taskforce (IOTF) criteria. Mothers' perceptions were assessed based on four possible conditions. The Kappa test ( $k$ ) was used to evaluate the correspondence between nutritional status and mothers' perceptions and followed by regression analyses. The prevalence of overweight and underweight was $23.2 \%$ and $5.7 \%$ respectively. Half of mothers reported that their children were "underweight"; $61.2 \%$ said that their children were "normal"; $11.8 \%$ said that their children were "above normal weight"; and $1.1 \%$ referred to their offspring as "very much above normal weight". Highest and lowest correspondence between nutritional status and mother's perception were: underweight and much above normal weight, respectively $(k=0.217, p<0.000)$. Gender and ethnicity showed significant association with the mother's perception, even after controlling for other variables. Low correspondence levels between nutritional status and mother's perception were observed, especially among obese children.

\author{
Maria del Carmen Bisi Molina ${ }^{1}$ \\ Carolina Perim de Faria ${ }^{2}$ \\ Pilar Montero 3 \\ Nagela Valadão Cade 2
}

\section{Introduction}

A mother's perception of her child's nutritional status is fundamental in that it determines patterns of care which define both in-house feeding practices and daily eating habits. This in turn affects the child's overall nutritional status. Often, once overweight is present, there is no correspondence between measured nutritional status and the individual's perception of their bodies 1 . Although many previous studies have pointed that women overestimate their nutritional status, studies focusing on identifying the correspondence levels among the "measured and quantified" body and the "perceived" body often use different approaches 2,3 .

Studies have shown that parents often underestimate either their children's obesity or overweight 4,5,6, and a range of factors underlie such misreading of their nutritional status. Younger and male children's weight, for example, are less accurately perceived, while older and male children's are better interpreted 7, especially by mothers with higher levels of education 8 .

This study aims at both investigating the correspondence between anthropometric evaluations of 7-10 year old children and their mothers' perceptions of their weight, and identifying the associated socio-demographic factors. 


\section{Methods}

A cross sectional quantitative design was chosen and data were collected and analyzed from a sample of 1,282 children aged 7-10, currently attending public and private schools in Vitória, Espírito Santo State, Brazil. The sample was planned to geographically cover the area of Vitória. In order to avoid interclass bias, conglomerate sampling was performed in two stages.

Anthropometric measurements were taken in each school by trained health personnel and performed using standardized procedures 9 . Criteria used to classify nutritional status followed Must et al. 10 and sociodemographic information was provided by parents or tutors. A multiple choice test was used to assess the mother's perception of her child's nutritional status. In order to study the main factors associated with maternal perception the following variables were investigated: child's sex and age, socioeconomic status, skin color (white vs. non white), type of school (public vs. private) and maternal level of schooling.

Variables were presented in percentages and the chi-square test was used to test for the hypothesis of homogenic proportions. Kappa was used to evaluate the correspondence between the children's nutritional status and maternal perception. Multivariate analysis was carried out through multinomial logistic regression procedures, with maternal perception as the dependent variable and normal weight as reference category. Significance level for variable inclusion in the model was established in 5\% for any of the dependent variable categories.

Statistical analysis was performed using SPSS for Windows (SPSS Inc., Chicago, USA). Adjusted odds ratio (OR) and 95\% confidence intervals (95\%CI) were calculated for the variables remaining in the multivariate model. Parents were fully informed of the study and signed a written consent form. The present study was approved by the Research Ethics Committee of the Universidade Federal do Espírito Santo (UFES - nº. 089/06).

\section{Results}

Table 1 shows the distribution of sociodemographic and anthropometric variables. Males and females presented no significant differences for any of the studied variables, including nutritional status. Skin color was positively associated with maternal education, socioeconomic status and type of school. Therefore, skin color was used as a socioeconomic status marker in the present study.
Maternal education was the only variable which presented a significant association with nutritional status ( $\mathrm{p}<0.000$ ). After adjusting for other socioeconomic and health related variables, association with overweight was still present (results not shown in the tables). The prevalence of underweight was greater among children born to unschooled mothers or mothers with fewer than eight years of education. The proportion of overweight and obese children was larger among mothers who completed high school.

Table 2 shows a poor correspondence between children's anthropometric classification and their mother's perception (kappa $=0.217$, $\mathrm{p}<0.000$ ). The greatest agreement rates were for underweight (72.6\%) and normal weight children (68.3\%). Better correspondence can be observed in underweight male children as compared to females (data not shown).

Statistically significant differences were found for maternal perception and gender, skin color and maternal level of schooling. Boys were perceived by their mothers as underweight more frequently than girls, the latter being perceived as overweight more often than boys. Non-white children were perceived as underweight in greater proportion than white children (results not shown on tables).

The analysis of adjusted data for maternal perception towards their children's nutritional status (Table 3) demonstrated that the only predictive variables for which an association was maintained throughout were gender and skin color. We found that males have a 1.78 (95\%CI: $1.37-2.31 ; \mathrm{p}<0.000)$ greater chance of being seen as underweight than females; also, having white skin lessens the chance of being perceived as underweight $(\mathrm{OR}=0.74$; 95\%CI: 0.56-0.99; $\mathrm{p}=$ 0.04 ) and triples the chance of being perceived as obese $(\mathrm{OR}=3.39 ; 95 \% \mathrm{CI}$ : $1.13-10.21 ; \mathrm{p}=0.03$ ).

\section{Discussion}

Most of the studies on this subject have been carried out with teenagers and adults, individuals capable of choosing and defining their lifestyles. The lifestyles and eating habits of children, on the other hand, are strictly dependent on their mothers or other adults both at home and at school. The quality and quantity of foods offered to children do not solely depend on consensual choices, as they are directly influenced by socioeconomic conditions 11 and the perception mothers have of their children's nutritional status 12 .

In this study, the correspondence between nutritional status and maternal perception was found to be low, especially among overweight 
Sample distribution according to nutritional status and sociodemographic variables. Vitória, Espírito Santo State, Brazil, 2007

\begin{tabular}{|c|c|c|c|c|c|c|}
\hline \multirow[t]{2}{*}{ Variable } & \multicolumn{3}{|c|}{ Gender } & \multicolumn{3}{|c|}{ Skin color } \\
\hline & $\begin{array}{l}\text { Male } \\
\text { n (\%) }\end{array}$ & $\begin{array}{c}\text { Female } \\
\text { n (\%) }\end{array}$ & $p$ value & $\begin{array}{l}\text { White } \\
\text { n (\%) }\end{array}$ & $\begin{array}{c}\text { Non-white } \\
\text { n (\%) }\end{array}$ & $p$ value \\
\hline \multicolumn{7}{|l|}{ Skin color } \\
\hline White & $176(42.0)$ & $243(58.0)$ & 0.920 & & & \\
\hline Non-white & $347(41.7)$ & $485(58.3)$ & & & & \\
\hline \multicolumn{7}{|c|}{ Maternal education (years) } \\
\hline$\leq 3$ & $129(24.7)$ & $200(27.3)$ & 0.750 & $60(14.5)$ & 269 (31.9) & 0.000 \\
\hline $4-10$ & $106(20.3)$ & $145(19.8)$ & & $64(15.5)$ & $187(22.2)$ & \\
\hline $11-14$ & $189(36.1)$ & $267(36.5)$ & & $144(34.9)$ & $312(37.1)$ & \\
\hline$\geq 15$ & $99(18.9)$ & $120(16.4)$ & & $145(35.1)$ & $74(8.8)$ & \\
\hline \multicolumn{7}{|c|}{ Socioeconomic class } \\
\hline$A+B$ & $113(43.1)$ & $149(56.9)$ & 0.854 & $69(19.2)$ & $193(25.3)$ & 0.002 \\
\hline C & $162(41.1)$ & $232(58.9)$ & & $152(42.3)$ & $242(31.7)$ & \\
\hline$D+E$ & $199(42.6)$ & $268(57.4)$ & & $138(38.4)$ & $329(43.1)$ & \\
\hline \multicolumn{7}{|l|}{ Type of school } \\
\hline Public & $446(42.0)$ & $615(58.0)$ & 0.911 & $277(66.1)$ & $784(90.8)$ & 0.000 \\
\hline Private & $92(41.6)$ & $129(58.4)$ & & $142(33.9)$ & $79(9.2)$ & \\
\hline \multicolumn{7}{|l|}{ Age (years) } \\
\hline 7 & $103(40.9)$ & $149(59.1)$ & 0.183 & $74(17.7)$ & $178(20.6)$ & 0.565 \\
\hline 8 & $139(38.7)$ & $220(61.3)$ & & $125(29.8)$ & $234(27.1)$ & \\
\hline 9 & $150(41.7)$ & $210(58.3)$ & & $117(27.9)$ & $243(28.2)$ & \\
\hline 10 & $146(46.9)$ & $165(53.1)$ & & $103(24.6)$ & 208 (24.1) & \\
\hline \multicolumn{7}{|l|}{ Nutritional status } \\
\hline Underweight & $32(43.8)$ & $41(56.0)$ & 0.828 & $17(4.1)$ & $56(6.5)$ & 0.216 \\
\hline Normal & $383(42.0)$ & $528(58.0)$ & & 305 (72.8) & $606(70.2)$ & \\
\hline Overweight & $72(39.3)$ & $111(60.7)$ & & $64(15.3)$ & 119 (13.8) & \\
\hline Obese & $51(44.0)$ & $64(55.7)$ & & 33 (7.9) & $82(9.5)$ & \\
\hline
\end{tabular}

Table 2

Correspondence between nutritional status of 7-10 year old children and their mothers' perceptions of their weight. Vitória, Espírito Santo State, Brazil, 2007.

\begin{tabular}{lcccc}
\hline Child's nutritional status & & Mother's perception of child's nutritional status \\
& Underweight & Normal & Overweight & Obese \\
& $\mathbf{n}(\%)$ & $\mathbf{n}(\%)$ & $1(1.4)$ & $0(0.0)$ \\
\hline Underweight & $53(72.6)$ & $19(26.0)$ & $15(1.7)$ & $0(0.0)$ \\
Normal & $271(30.0)$ & $616(68.3)$ & $60(33.0)$ & $2(1.1)$ \\
Overweight & $4(2.2)$ & $116(63.7)$ & $75(65.2)$ & $12(10.4)$ \\
\hline
\end{tabular}

Kappa $=0.217, \mathrm{p}<0.000$

and obese children. Similar low results were found in a study undertaken with Australian preschool children 13 . In general, mothers more frequently perceive their children as underweight 6,14; even though significant differences were ob- served when these perceptions were associated with sociocultural factors and gender 8,15. These are the variables which our study found to best account for the mismatch between maternal perception and nutritional status. It should be noted 
Factors associated with mother's perception of their child's nutritional status: adjusted odds ratio (OR) with respective confidence intervals (95\% Cl). Vitória, Espírito Santo State, Brazil, 2007.

\begin{tabular}{|c|c|c|c|c|c|}
\hline \multirow{2}{*}{$\begin{array}{l}\text { Mother's } \\
\text { perception/Variable }\end{array}$} & \multirow[t]{2}{*}{$\beta$ coefficient } & \multirow[t]{2}{*}{$p$ value } & \multirow[t]{2}{*}{ OR } & \multicolumn{2}{|c|}{$95 \% \mathrm{Cl}$} \\
\hline & & & & Lowest & Highest \\
\hline \multicolumn{6}{|l|}{ Underweight } \\
\hline \multicolumn{6}{|l|}{ Gender } \\
\hline Male/Female & 0.574 & 0.000 & 1.78 * & 1.368 & 2.305 \\
\hline \multicolumn{6}{|l|}{ Skin color } \\
\hline White/Non white & -0.297 & 0.040 & 0.74 * & 0.559 & 0.987 \\
\hline \multicolumn{6}{|l|}{ Overweight } \\
\hline \multicolumn{6}{|l|}{ Gender } \\
\hline Male/Female & -0.180 & 0.334 & 0.83 & 0.579 & 1.204 \\
\hline \multicolumn{6}{|l|}{ Skin color } \\
\hline White/Non white & -0.190 & 0.323 & 0.83 & 0.567 & 1.205 \\
\hline \multicolumn{6}{|l|}{ Obesity } \\
\hline \multicolumn{6}{|l|}{ Gender } \\
\hline Male/Female & 0.166 & 0.761 & 1.18 & 0.405 & 3.445 \\
\hline \multicolumn{6}{|l|}{ Skin color } \\
\hline White/Non white & 1.221 & 0.030 & 3.39 * & 1.125 & 10.215 \\
\hline
\end{tabular}

* $p$ value $\leq 0.000$

that skin color was used as a socioeconomic status marker.

In our sample, we observed that non-white children were born to women who consistently had lower schooling and income. Our results point to the fact that mothers with higher schooling and income seem to be able to identify more accurately their children's health concerns, both physical and psychological (such as obesity and low body image), than low schooling and income level mothers. Similar results were found in a study performed in the United States 15.

Also, mothers with higher educational levels have more access to information and can afford the tools to fight their children's overweight, while mothers of lower socioeconomic status and schooling are often less aware of preventive actions and less equipped to implement treatment if necessary.

Mothers tend to perceive their children as thinner than they really are, and this is especially true for males. This can be related to a gender issue difference in which girls are led to pursue and value thinness more than boys. Although there is no significant difference in the proportion of different weight categories in this study, previous population studies undertaken with adults have shown a decrease in the proportion of overweight among women of higher socioeconomic status. On the other hand, men are growing heavier in all socioeconomic classes 16 . Actually, for this sam- ple, self-reported body mass index (BMI) values for fathers were found to be higher than those for mothers; the former were associated with excessive body weight of their children, which may indicate that gender influences maternal perception and concerns about the daughters' health and nutritional status.

\section{Final considerations}

Maternal concerns about their children's body image differ from sons to daughters, and this may bring about gender-related risk factors: increase of overweight and obesity in boys during their growth period from childhood into adulthood, eating disorders (anorexia, bulimia) in girls triggered by low body image. Although the correspondence between nutritional status and maternal perception of the children's body image was low in this study, it may ultimately depend on socioeconomic status and the children's gender. 


\section{Resumo}

Para investigar a correspondência entre classificação antropométrica de crianças e percepção de peso referida por suas mães, foi realizado estudo com 1.282 crianças (7-10 anos). Utilizou-se o critério recomendado pela International Obesity Task Force (IOTF) para avaliação antropométrica e a percepção foi aferida por meio de pergunta objetiva. Teste de kappa foi usado para avaliação da correspondência. A percepção materna foi associada a fatores sócio-demográficos, utilizando-se modelo de regressão logística multinominal $(\alpha=0,05)$. A prevalência de excesso de peso e baixo peso foi de $23,2 \%$ e $5,7 \%$, respectivamente. Vinte e cinco vírgula oito por cento das mães disseram que seus filhos estão "abaixo do peso", 61,2\% disseram que seus filhos estão "normais", 11,8\% disseram que seus filhos estão "acima do peso" e 1,1\% "muito acima do peso". Baixo peso e muito acima do peso obtiveram a maior e a menor correspondência, respectivamente (kappa $=$ $0,217, p<0,000)$. Gênero e cor da pele mostraram associação significativa com percepção materna, mesmo após ajuste por outras variáveis. Observou-se baixa correspondência entre classificação antropométrica e percepção materna, especialmente entre crianças classificadas como obesas.

Estado Nutricional; Imagem Corporal; Antropometria

\section{References}

1. Gualdi-Russo E, Albertini A, Argnani L, Celenza F, Nicolucci M, Toselli S. Weight status and body image perception in Italian children. J Hum Nutr Diet 2008; 21:39-45.

2. Braga PD, Molina MCB, Figueiredo TAM. Representações do corpo: com a palavra um grupo de adolescentes de classes populares. Ciênc Saúde Coletiva; in press.

3. Montero P, Morales E, Carbajal A. Valoración de la percepción de la imagen corporal mediante modelos anatómicos. Antropo 2004; 8:107-16.

4. Hirschler DV, González C, Cemente G, Talgham S, Petticnichio H, Jadzinsky M. ¿Cómo perciben las madres de niños de jardín de infantes a sus hijos con sobrepeso? Arch Argent Pediatr 2006; 104:221-6.

\section{Contributors}

M. C. B. Molina was responsible for data analysis, article conception and write up. C. P. Faria participated in the write up and analysis of the article. P. Montero participated in the conception and revision of the article and data analysis. N. V. Cade revised the manuscript.

\section{Acknowledgments}

The study received financial support from the Fundo de Apoio à Ciência e à Tecnologia de Vitória (FACITEC).
5. Jeffery AN, Voss LD, Metcalf BS, Alba S, Wilkin TJ. Parents' awareness of overweight in themselves and their children: cross sectional study within a cohort (EarlyBird 21). BMJ 2005; 330:23-4.

6. Mamun AA, McDermott BM, O'Callaghan MJ, Najman JM, Williams GM. Predictors of maternal misclassifications of their offspring's weight status: a longitudinal study. Int J Obes 2008; 32:48-54.

7. Maynard LM, Galuska DA, Blanck HM, Serdula MK. Maternal perceptions of weight status of children. Pediatrics 2003; 111:1226-31.

8. Baughcum AE, Chamberlin LA, Deeks CM, Powers SW, Whitaker RC. Maternal perceptions of overweight preschool children. Pediatrics 2000; 106:1380-6. 
9. World Health Organization. Physical status: the use and interpretation of anthropometry indicators of nutritional status. Geneva: World Health Organization; 1995. (Technical Report Series, 854).

10. Must A, Dallal GE, Dietz WH. Reference data for obesity: 85th and 95th percentiles of body mass index (wt/ $\left.\mathrm{ht}^{2}\right)$ and triceps skinfold thickness. Am J Clin Nutr 1991; 53:839-46.

11. Mendoza JA, Drewnowski A, Cheadle A, Christakis DA. Dietary energy density is associated with selected predictors of obesity in U.S. children. J Nutr 2006; 136:1318-22.

12. Etelson D, Brand DA, Patrick PA, Shirali A. Childhood obesity: do parents recognize this health risk? Obes Res 2003; 11:1362-8.

13. Campbell MW, Williams J, Hampton A, Wake M. Maternal concern and perceptions of overweight in Australian preschool-aged children. Med J Aust 2006; 184:274-7.
14. Barba G, Casullo C, Russo P, Siani A; ARCA Project Study Group. Gender inequalities in maternal perception of healthy child body shape and their association with child body mass and blood pressure. Int J Pediatr Obes 2008; 3:78-83.

15. Welch C, Gross SM, Bronner Y, Dewberry-Moore N, Paige DM. Discrepancies in body image perception among fourth-grade public school children from urban, suburban, and rural Maryland. J Am Diet Assoc 2004; 104:1080-5.

16. Instituto Brasileiro de Geografia e Estatística. Pesquisa de Orçamentos Familiares 2002-2003: análise da disponibilidade domiciliar de alimentos e do estado nutricional no Brasil. Rio de Janeiro: Instituto Brasileiro de Geografia e Estatística; 2004.

\section{Submitted on 13/Nov/2008}

Final version resubmitted on 19/Jul/2009 Approved on 29/Jul/2009 